\title{
Estimation of ice thickness using surface velocities and slope: case study at Gangotri Glacier, India
}

\author{
Prateek GANTAYAT, Anil V. KULKARNI, J. SRINIVASAN \\ Divecha Centre for Climate Change, Indian Institute of Science, Bangalore, India \\ E-mail: gantayat.prateek@ymail.com
}

\begin{abstract}
We estimate the distribution of ice thickness for a Himalayan glacier using surface velocities, slope and the ice flow law. Surface velocities over Gangotri Glacier were estimated using sub-pixel correlation of Landsat TM and ETM+ imagery. Velocities range from $\sim 14-85 \mathrm{~m} \mathrm{a}^{-1}$ in the accumulation region to $\sim 20-30 \mathrm{~m} \mathrm{a}^{-1}$ near the snout. Depth profiles were calculated using the equation of laminar flow. Thickness varies from $\sim 540 \mathrm{~m}$ in the upper reaches to $\sim 50-60 \mathrm{~m}$ near the snout. The volume of the glacier is estimated to be $23.2 \pm 4.2 \mathrm{~km}^{3}$.
\end{abstract}

KEYWORDS: glacial rheology, glacier flow, glacier modelling, remote sensing

\section{INTRODUCTION}

The volume of a glacier is an important parameter in assessing a glacier's health. Rough terrain and harsh climatic conditions in the Himalaya limit the number of field studies. Therefore, the volume/area scaling method has been utilized to calculate mean depth or volume of ice. The Himalaya and Karakoram are among the largest reservoirs of ice after the polar regions, extending over an area $>40000 \mathrm{~km}^{2}$ (Bolch and others, 2012). Recent observations suggest that most of the Himalayan glaciers are retreating at different rates (Kulkarni and others, 2007, 2011; Bhambri and Bolch, 2009; Hewitt, 2011; Iturrizaga, 2011; Venkatesh and others, 2012). Due to a lack of sufficient information, especially about ice thickness, the sustainability of Himalayan glaciers is difficult to assess, and there are wide differences reported for their current rates of mass loss and long-term health (Raina, 2009; Jacob and others, 2012).

Two of the major parameters used to characterize glacier dynamics are surface velocity and ice thickness. Several methods have been used in the past to determine the volume of a glacier. The first statistical method was based on estimating the mean depth from surface area (Müller, 1970). This rule for Alpine glaciers has been adopted for Himalayan glaciers, with few departures (Raina and Srivastava, 2008). Power-law relationships for volume/area, volume/length and volume/area/length have been derived from the abundant information available regarding area and length (Chen and Ohmura, 1990; Bahr and others, 1997; Radić and others, 2008). Volume/area scaling is essentially an inversion, because unseen parameters, such as depth, can be inferred from surface area (Lliboutry, 1987). Due to over-specification of data at some boundaries and underspecification at others, an ill-posed boundary-value problem is formed (Lliboutry, 1987), making the solution inherently unstable, non-unique and sensitive to small changes at the over-specified boundary at the surface (Bahr and others, 2013).

Artificial neural network methods have also been employed, using calculations based on a digital elevation model (DEM) and a mask of present-day ice cover in the Mount Waddington area in British Columbia and Yukon, Canada (Clarke and others, 2009). Due to the lack of suitable data from known glaciers, the artificial neural network approach is trained by substituting the known topography of ice-free regions, adjacent to the ice-covered regions of interest. The known topography is then hidden by imaging it to be ice-covered. The maximum relative uncertainty in volume estimates was $45 \%$.

Ice volume was calculated for Columbia Glacier, Alaska, USA, by estimating ice fluxes using the equation of continuity between adjacent flowlines (McNabb and others,

2012). In that investigation surface velocities and mass balance were used to estimate mean ice flux.

Farinotti and others (2009a) developed another approach, using apparent mass balance to estimate ice thickness. From a distribution of apparent mass balance, ice flux was computed over selected ice flowlines and was then converted to ice thickness using Glen's flow law (Glen, 1955). Using this method, the ice-thickness distribution and volumes were estimated for glaciers in the Swiss Alps and elsewhere (Farinotti and others, 2009b; Huss and Farinotti, 2012). Mass-balance distribution data over large glaciers in the Himalaya are not easily available and are inaccurate in some cases (Bolch and others, 2012). In this paper, therefore, we estimate the icethickness distribution over Gangotri Glacier using surface velocities, slope and the flow law of ice. The surface velocities were estimated using remote-sensing techniques (Leprince and others, 2007).

\section{STUDY AREA}

Our study concerns Gangotri Glacier (Fig. 1). It is $30.2 \mathrm{~km}$ long, has a mean width of $1.5 \mathrm{~km}$ and is one of the largest glaciers in the Himalaya. The surface elevation ranges from 4000 to 7000 ma.s.l. (Jain, 2008) and the surface area is $140 \mathrm{~km}^{2}$. The glacier has six tributary glaciers, as shown in Figure 1.

\section{METHODOLOGY}

Landsat Thematic Mapper (TM) and Enhanced TM Plus (ETM+) imagery (30 $\mathrm{m}$ spatial resolution) was obtained for 2009 and 2010 (Table 1), during September and October, i.e. at the end of the melting season (http://earthexplorer. usgs.gov/). The post-monsoon months were chosen to ensure minimum cloud cover over the area of interest. 


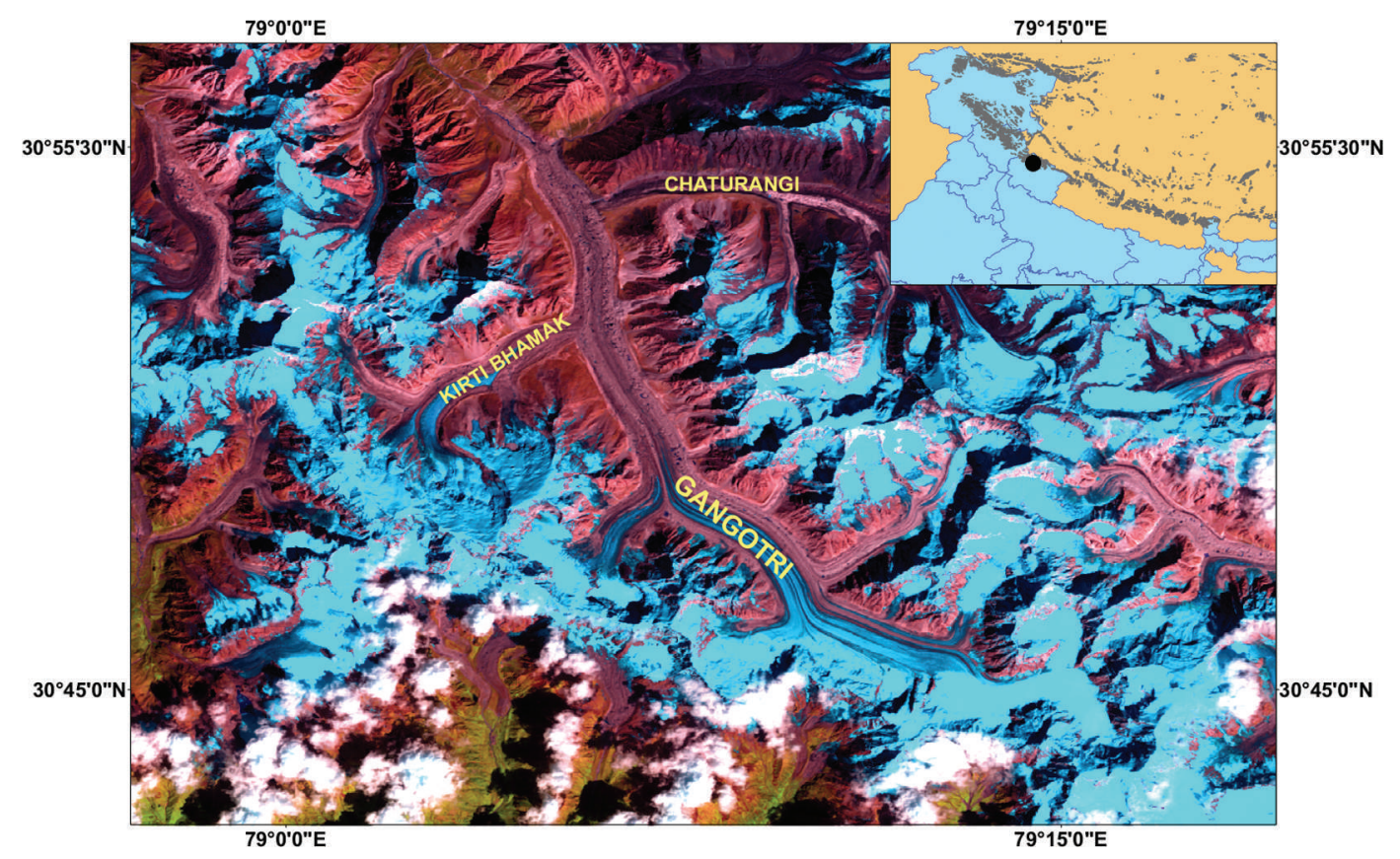

Fig. 1. Location of Gangotri Glacier in the Indian Himalaya. The tributary glaciers Kirti Bhamak and Chaturangi are also shown. This is one of the largest glaciers in the Central Himalaya.

\section{Calculation of surface velocity fields}

Surface velocities were calculated using sub-pixel correlation of the acquired images, using the freely available software Co-registration of Optically Sensed Images and Correlation (COSI-Corr), which is downloadable at http:// www.tectonics.caltech.edu/. In this algorithm, two images are iteratively cross-correlated in the phase plane on sliding windows, to find the best possible correlation. A detailed description of the algorithm is given by Leprince and others (2007). After performing sub-pixel correlation, taking a sliding window of $32 \times 32$ pixels and a step size of two pixels we have three output images: a north/south displacement image, an east/west displacement image and a signalto-noise ratio (SNR) image that describes the quality of correlation. All pixels that have $\mathrm{SNR}<0.9$ and displacements $>85 \mathrm{~m}$ are discarded. A vector field is generated from the two displacement images and is then overlaid on the image. After verifying the proper alignment of the displacement vectors along the length of the glacier, the Eulerian norm of the displacement images is calculated to find the magnitude of the resultant displacement. The difference in the time of acquisition between the two images is used to estimate the velocity field.

\section{Estimation of depth}

Ice thickness is estimated using the equation of laminar flow (Cuffey and Paterson, 2010):

$$
U_{\mathrm{s}}=U_{\mathrm{b}}+\frac{2 A}{n+1} \tau_{\mathrm{b}}^{\mathrm{n}} H,
$$

where $U_{\mathrm{s}}$ and $U_{\mathrm{b}}$ are surface and basal velocities, respectively. To date, no accurate estimate of basal velocity for Gangotri Glacier is available, so we assumed $U_{\mathrm{b}}$ to be $25 \%$ of the surface velocity (Swaroop and others, 2003). Glen's flow law exponent, $n$, is assumed to be $3, H$ is ice thickness and $A$ is a creep parameter (which depends on temperature, fabric, grain size and impurity content and has a value of $3.24 \times 10^{-24} \mathrm{~Pa}^{-3} \mathrm{~s}^{-1}$ for temperate glaciers; Cuffey and
Paterson, 2010). The basal stress is modelled as

$$
\tau_{\mathrm{b}}=f \rho g H \sin \alpha,
$$

where $\rho$ is the ice density, assigned a constant value of $900 \mathrm{~kg} \mathrm{~m}^{-3}$ (Farinotti and others, 2009a), $g$ is acceleration due to gravity $\left(9.8 \mathrm{~m} \mathrm{~s}^{-2}\right)$ and $f$ is a scale factor, i.e. the ratio between the driving stress and basal stress along a glacier, and has a range of $[0.8,1]$ for temperate glaciers. We use $f=0.8$ (Haeberli and Hoelzle, 1995). Slope, $\alpha$, is estimated from ASTER (Advanced Spaceborne Thermal Emission and Reflection Radiometer) DEM elevation contours, at $100 \mathrm{~m}$ intervals (http://reverb.echo.nasa.gov/reverb). This interval was chosen so the surface slope is averaged over a reference distance that is about an order of magnitude larger than the local ice thickness (e.g. Kamb and Echelmeyer, 1986; Cuffey and Paterson, 2010; Linsbauer and others, 2012).

From Eqns (1) and (2) we find

$$
H=\sqrt[4]{\frac{1.5 U_{\mathrm{s}}}{A f^{3}(\rho g \sin \alpha)^{3}}},
$$

from which a depth for each area between successive $100 \mathrm{~m}$ contours is calculated. Finally, all these depths are plotted to provide an ice-thickness distribution for the entire glacier. The ice-thickness values are then smoothed using a $3 \times 3$ kernel, in order to remove any abrupt changes in spatial icethickness values.

Table 1. Description of datasets used for analysis

Data

Date of acquisition Band Resolution

$\mathrm{m}$

$\begin{array}{lccc}\text { LT51460392009282KHC00_B4 } & \text { 9 October 2009 } & 4 & 30 \\ \text { LT51460392010301KHC00_B4 } & \text { 26 September 2010 } & 4 & 30 \\ \text { LE71950282004236ASN01_B4 } & \text { 23 August 2004 } & 4 & 30 \\ \text { LE71950282005222EDC00_B4 } & \text { 10 August 2005 } & 4 & 30\end{array}$




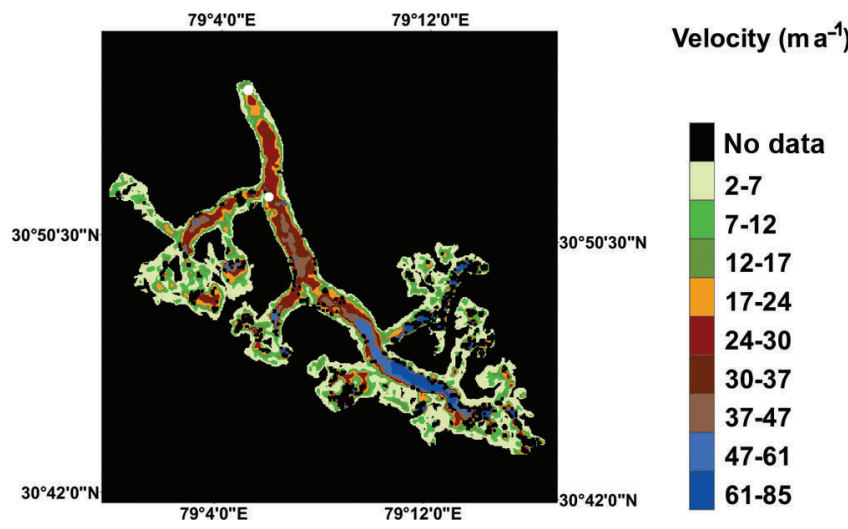

Fig. 2. Surface velocity field of Gangotri Glacier. The maximum velocities are found in the higher reaches and vary from 61 to $85 \mathrm{~m} \mathrm{a}^{-1}$. The minimum velocities are found near the snout and at the glacier boundary, and vary from 5 to $15 \mathrm{~m} \mathrm{a}^{-1}$. The two large white dots represent the sites where surface velocity was determined by field investigation.

\section{Uncertainty analysis}

The uncertainty in depth estimates is quantified by taking the natural logarithm of both sides of Eqn (3) and then differentiating:

$$
\frac{\mathrm{d} H}{H}=0.25\left[\frac{\mathrm{d} U_{\mathrm{s}}}{U_{\mathrm{s}}}-\frac{\mathrm{d} A}{A}-3 \frac{\mathrm{d} f}{f}-3 \frac{\mathrm{d} \rho}{\rho}-3 \frac{\mathrm{d}(\sin \alpha)}{(\sin \alpha)}\right] .
$$

\section{RESULTS}

The surface velocities for Gangotri Glacier are shown in Figure 2. The velocities peak in the upper trunk section, reaching a value of $\sim 85 \mathrm{~m} \mathrm{a}^{-1}$, and progressively decrease to $<30 \mathrm{~m} \mathrm{a}^{-1}$ in the lower reaches.

The ice-thickness distribution for Gangotri Glacier is shown in Figure 3a. Ice thickness attains a maximum of $540 \mathrm{~m}$ in the central part of the glacier's main trunk. A thickness distribution range of 350-450 m was estimated in the upper reaches, while in the lower reaches the range was 150-200 m. At the snout the thickness was estimated to be in the range $40-65 \mathrm{~m}$. Two cross-profiles at different positions on the glacier were plotted and are shown in Figure $3 \mathrm{~b}$.

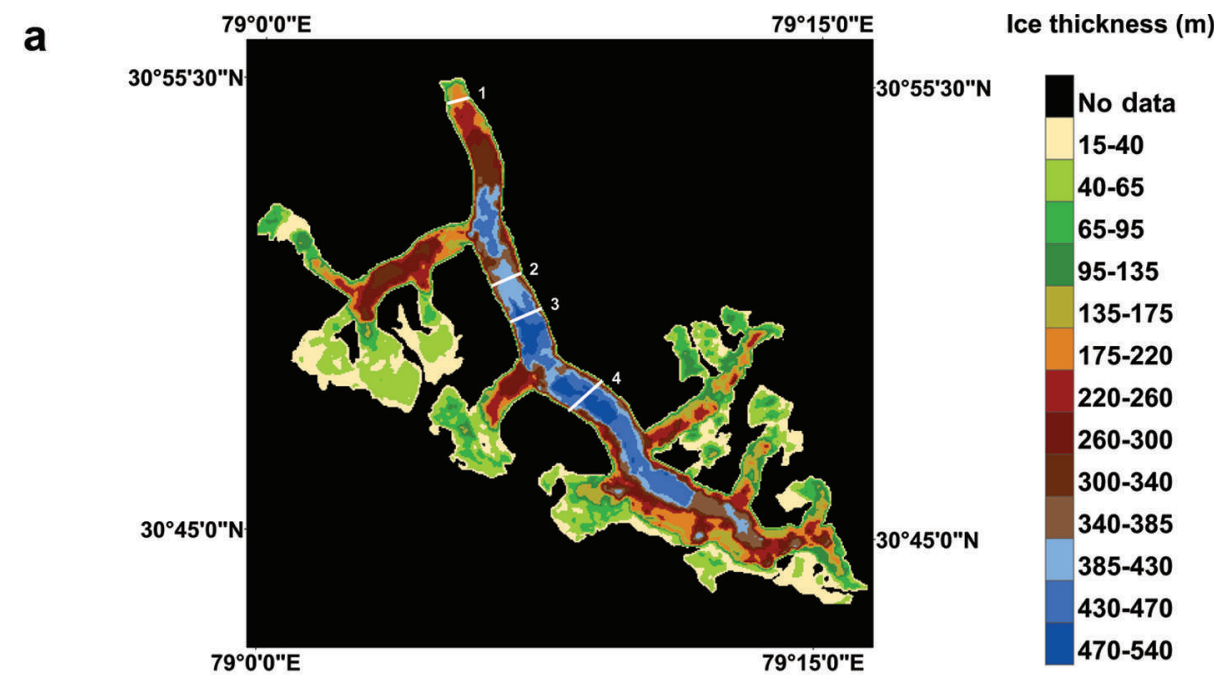

b
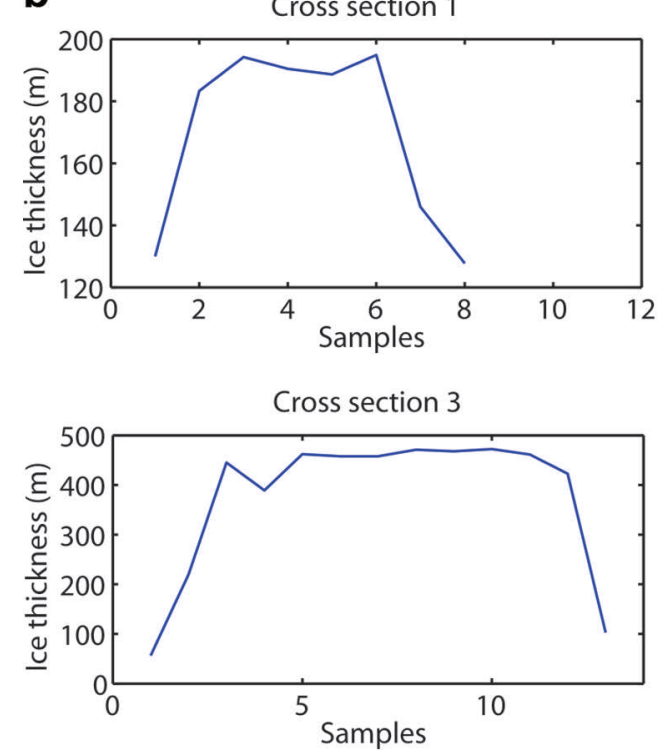

Cross section 2
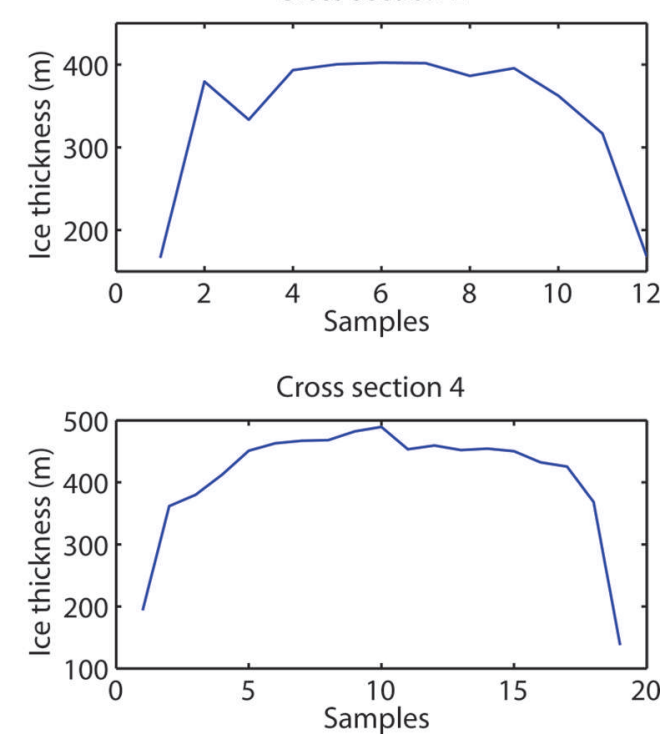

Fig. 3. (a) Ice-thickness distribution of Gangotri Glacier. Maximum ice thickness is $\sim 540 \mathrm{~m}$ in the central part of the main trunk. At the snout the thickness is estimated to be in the range $40-65 \mathrm{~m}$. (b) The ice-thickness distribution along four cross-sectional profiles (1-4). 

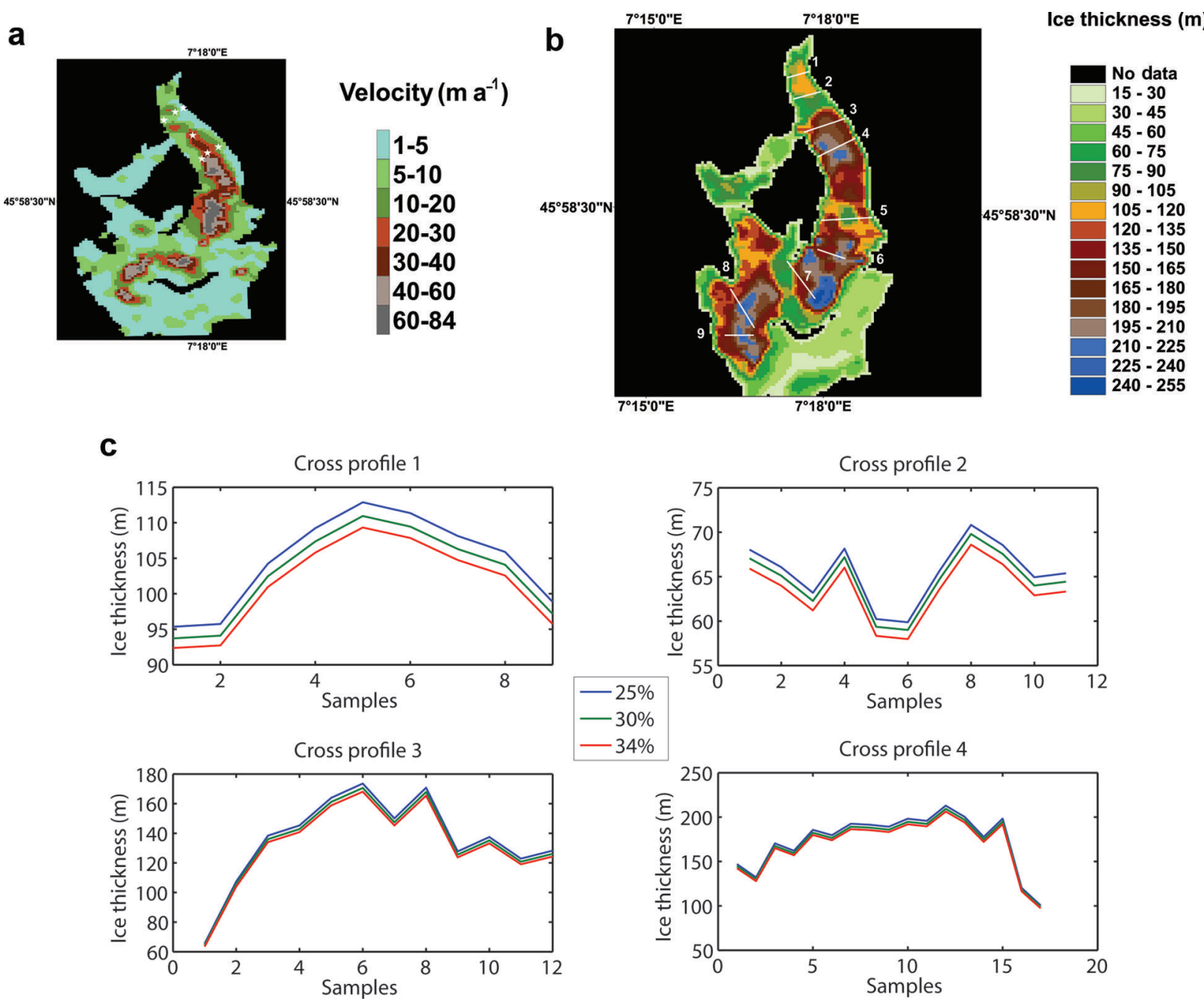

Fig. 4. (a) Velocity field of Glacier de Corbassière. The maximum velocity varies from 60 to $84 \mathrm{~m} \mathrm{a}^{-1}$. The minimum velocity varies from 3 to $10 \mathrm{~m} \mathrm{a}^{-1}$. The white stars indicate sites where velocity was measured in the field (Glaciological Reports, 2009). (b) Ice-thickness distribution of Glacier de Corbassière (Gabbi and others, 2012; Linsbauer and others, 2012). Ground-penetrating radar soundings were made at nine cross sections, numbered 1-9. (c) Sensitivity of ice thickness to three values of basal velocity, expressed as per cent surface velocity: red $34 \%$, green $-30 \%$, blue $-25 \%$. The plots show the four cross sections of Glacier de Corbassière numbered $1-4$ in (b). The ice thickness varies negligibly, even when basal velocity is varied by $10 \%$.

\section{Validation}

We validated the surface velocity field estimated over Gangotri Glacier using data collected during 1971 and 1972 (Swaroop and others, 2003). There are no direct icethickness measurements for Gangotri Glacier. However, there is an extensive set of direct measurements for both velocity field and ice thickness for Glacier de Corbassière, Swiss Alps, so we were able to validate our technique by estimating the velocity fields and ice-thickness distribution of the Alpine glacier using the same set of parameters as we had used for Gangotri Glacier.

The 1971 and 1972 field measurements of surface velocities (Swaroop and others, 2003) at the confluence of Kirti Bhamak Glacier and at Raktvarn Glacier (near the snout) are indicated by white dots in Figure 2. We assume that when the observations were made, the velocities were similar to those at present, meaning that the velocities we calculate here are comparable with those observed in the 1971 and 1972 field studies. Near Kirti Bhamak Glacier the difference (modelled values minus observed values) was $\sim 4 \mathrm{~m} \mathrm{a}^{-1}$, and near Raktvarn Glacier it was $3 \mathrm{~m} \mathrm{a}^{-1}$. The modelled outputs are thus slightly higher than those observed.
Surface velocity and ice-thickness distribution are calculated for Glacier de Corbassière $\left(45.9903^{\circ} \mathrm{N}, 7.2639^{\circ} \mathrm{E}\right)$ using Landsat ETM+ imagery for 2004 and 2005 (Table 1) and were compared with observations (Glaciological Reports, 2009; Gabbi and others, 2012). The velocity and ice-thickness profiles are presented in Figure 4.

The velocity profiles of Glaciological Reports (2009) were compared at the sites indicated by white stars in Figure 4a. The absolute error for each point was found to be $<6 \mathrm{~m} \mathrm{a}^{-1}$ for all but one of the seven points.

The ice-thickness profile was estimated using the same approach, and was compared with that estimated by Gabbi and others (2012) and Linsbauer and others (2012). Groundpenetrating radar (GPR) profiles were available for four cross sections, numbered 1-9 in Figure 4b. Since GPR soundings give point-to-point measurements, while our thickness profile is over an area of $3600 \mathrm{~km}^{2}$, differences between the means of observed thickness values and modelled thickness values were computed. The relative differences were $5 \%, 0 \%, 12.3 \%, 28.9 \%, 17 \%, 15 \%, 7 \%, 9.9 \%$ and $5 \%$ for cross sections 1, 2, 3, 4, 5, 6, 7, 8 and 9, respectively. Except for cross sections 5 and 6, the modelled values were 
slightly higher than those observed. The total volume of stored ice from our investigation is $\sim 1.8 \pm 0.5 \mathrm{~km}^{3}$. This compares well with the estimates of Gabbi and others (2012) and Farinotti and others (2009b), who suggest values of $1.36 \pm 0.07$ and $1.96 \mathrm{~km}^{3}$, respectively.

\section{UNCERTAINTY AND SENSITIVITY ANALYSIS}

Uncertainties in the estimation of ice thickness depend on: (1) uncertainty in velocity estimates; (2) uncertainty in the creep parameter, $A$; (3) uncertainty in the shape factor, $f$; (4) uncertainty in the density of ice; and (5) uncertainty in estimation of slope angle, $\alpha$.

There are two sources of uncertainty in velocity estimates. (1) The uncertainty introduced due to orthorectification errors can be determined by examining the displacements over icefree ground (where the displacements may be assumed to be zero). In our analyses, all the pixels that represented displacement over ice-free ground showed a root-mean-square displacement of 5-9 m, with a maximum of $12 \mathrm{~m}$. (2) Uncertainty is also introduced by decorrelation caused by the presence of cloud cover over the glaciers. For this reason, we only used images with minimal cloud cover over the region of interest. Seasonal snow cover also biases the velocity measurements by masking the features present on the glacier surface, due to which the algorithm fails. Therefore only images at the end of the melting season were analysed. Decorrelation can also occur at the snout, due to melting or changes in land surface characteristics caused by landslides.

In order to quantify the total uncertainty (for a particular value of basal velocity, i.e. $25 \%$ of surface velocity) in volume estimation using Eqn (4), we fix the values for $\mathrm{d} U_{\mathrm{s}}$ $\mathrm{d} f, \mathrm{~d} \rho, \mathrm{d}(\sin \alpha) /(\sin \alpha)$ and $\mathrm{d} A$. The reason we do not consider variation in basal velocity can be seen from Figure 4c, which shows the variation of ice-thickness estimates for three values of basal velocity. The ice thickness varies by a very small magnitude for a given range of basal velocities (expressed as per cent of surface velocity).

The value of $\mathrm{d} U_{\mathrm{s}}$ was fixed as $3.5 \mathrm{ma}^{-1}$, which is the average of the differences (between observed and modelled outputs) obtained at the two sites by Swaroop and others (2003), and $d f$ was set to 0.1. In the literature (e.g. Hubbard and others, 1998; Gudmundsson, 1999; Farinotti and others, 2009a) $A$ is set to $2.4 \times 10^{-24} \mathrm{~Pa}^{-3} \mathrm{~s}^{-1}$. We set $\mathrm{d} A$ to be the difference between the value assigned by us and $2.4 \times 10^{-24} \mathrm{~Pa}^{-3} \mathrm{~s}^{-1}$. To estimate the uncertainty in slope angle over a region, the vertical accuracy of the DEM must be known. The potential uncertainty in the ASTER DEM for the Himalayan region is $11 \mathrm{~m}$ (Fujita and others, 2004). Therefore, the term $\mathrm{d}(\sin \alpha) /(\sin \alpha)$ has a value of 0.09 . Variation in ice density, $\rho$, over the depth of the glacier is not known. We assume relative uncertainties of $10 \%$, and take $\mathrm{d} \rho$ as $90 \mathrm{~kg} \mathrm{~m}^{-3}$.

Substituting these values into Eqn (4), we find the maximum relative error in the volume measurement for Gangotri Glacier is $\pm 18.1 \%$ (assuming that the parameters vary independently and randomly).

\section{CONCLUSIONS}

We have estimated the ice thickness for Gangotri Glacier from surface velocities and slope, using the flow law of ice. The velocities varied from 14 to $85 \mathrm{ma}^{-1}$ in the upper reaches and were $<30 \mathrm{~m} \mathrm{a}^{-1}$ in the lower reaches. The ice thickness attained a maximum value of $\sim 540 \mathrm{~m}$; a range of 350-450 $\mathrm{m}$ was found in the upper reaches; in the lower reaches the range was $150-200 \mathrm{~m}$ and at the snout it was $50-65 \mathrm{~m}$. The total volume of Gangotri Glacier is $\sim 23.2 \pm 4.2 \mathrm{~km}^{3}$ (18\% uncertainty). These analyses show that the method has the potential to improve estimates of the ice-thickness distribution of glaciers where massbalance data are not available, as is the case for most large Himalayan glaciers. This will help in assessing the sustainability of Himalayan glaciers.

\section{ACKNOWLEDGEMENTS}

We thank the Divecha Centre for Climate Change for providing laboratory resources. We also thank Sébastien Leprince for vital suggestions during the calculation of displacement maps over the glacier. We are grateful to the US Geological Survey for its free data policy, allowing us to use Landsat TM/ETM+ imagery. We thank Helgi Björnsson for valuable insights into glacier dynamics, which helped us to carry out this analysis.

\section{REFERENCES}

Bahr DB (1997) Width and length scaling of glaciers. J. Glaciol., 43(145), 557-562

Bahr DB, Pfeffer WT and Kaser G (2013) Glacier volume estimation as an ill-posed boundary value problem. Cryos. Discuss., 6(6), 5405-5420 (doi: 10.5194/tcd-6-5405-2012)

Bhambri R and Bolch T (2009) Glacier mapping: a review with special reference to the Indian Himalayas. Progr. Phys. Geogr., 33(5), 672-704 (doi: 10.1177/0309133309348112)

Bolch Tand 11 others (2012) The state and fate of Himalayan glaciers. Science, 336(6079), 310-314 (doi: 10.1126/science.1215828)

Chen J and Ohmura A (1990) Estimation of Alpine glacier water resources and their change since the 1870s. IAHS Publ. 193 (Symposium at Lausanne 1990 - Hydrology in Mountainous Regions), 127-135

Clarke GKC, Berthier E, Schoof CG and Jarosch AH (2009) Neural networks applied to estimating subglacial topography and glacier volume. J. Climate, 22(8), 2146-2160 (doi: 10.1175/ 2008JCLI2572.1)

Cuffey KM and Paterson WSB (2010) The physics of glaciers, 4th edn. Butterworth-Heinemann, Oxford

Farinotti D, Huss M, Bauder A, Funk M and Truffer M (2009a) A method to estimate ice volume and ice-thickness distribution of alpine glaciers. J. Glaciol., 55(191), 422-430 (doi: 10.3189/ 002214309788816759)

Farinotti D, Huss M, Bauder A and Funk M (2009b) An estimate of the glacier ice volume in the Swiss Alps. Global Planet. Change, 68(3), 225-231 (doi: 10.1016/j.gloplacha.2009.05.004)

Fujita K, Suzuki R, Nuimura T and Sakai A (2008) Performance of ASTER and SRTM DEMs and their potential for assessing glacial lakes in the Lunand region, Bhutan Himalaya. J. Glaciol., 54(185), 220-228

Gabbi J, Farinotti D, Bauder A and Maurer H (2012) Ice volume distribution and implications on runoff projections in a glacierized catchment. Hydrol. Earth Syst. Sci., 16(12), 4543-4556 (doi: 10.5194/hess-16-4543-2012)

Glaciological Reports (2009) The Swiss Glaciers 2003/04 and 2004/05, ed. Bauder A and Rüegg R. (Yearbooks of the Cryospheric Commission of the Swiss Academy of Sciences (SCNAT) 125-126) VAW-ETHZ, Zürich http://glaciology.ethz.ch/ swiss-glaciers

Glen JW (1955) The creep of polycrystalline ice. Proc. R. Soc. London, Ser. A, 228(1175), 519-538

Gudmundsson $\mathrm{GH}$ (1999) A three-dimensional numerical model of the confluence area of Unteraargletscher, Bernese Alps, 
Switzerland. J. Glaciol., 45(150), 219-230 (doi: 10.3189/ 002214399793377086)

Haeberli W and Hoelzle M (1995) Application of inventory data for estimating characteristics of and regional climate-change effects on mountain glaciers: a pilot study with the European Alps. Ann. Glaciol., 21, 206-212

Hewitt K (2011) Glacier change, concentration, and elevation effects in the Karakoram Himalaya, upper Indus basin. Mt. Res. Dev., 31(3), 188-200 (doi: 10.1659/MRD-JOURNAL-D-1100020.1)

Hubbard A, Blatter H, Nienow P, Mair D and Hubbard B (1998) Comparison of a three-dimensional model for glacier flow with field data from Haut Glacier d'Arolla, Switzerland. J. Glaciol., 44(147), 368-378

Huss M and Farinotti D (2012) Distributed ice thickness and volume of all glaciers around the globe. J. Geophys. Res., 117(F4), F04010 (doi: 10.1029/2012JF002523)

Iturrizaga L (2011) Trends in 20th century and recent glacier fluctuations in the Karakoram Mountains. Z. Geomorph., 55(Suppl. 3), 205-231 (doi: 10.1127/0372-8854/2011/ 0055S3-0059)

Jacob T, Wahr J, Pfeffer WT and Swenson S (2012) Recent contributions of glaciers and ice caps to sea level rise. Nature, 482(7386), 514-518 (doi: 10.1038/nature10847)

Jain SK (2008) Impact of retreat of Gangotri glacier on the flow of Ganga river. Current Sci., 95(8), 1012-1014

Kamb B and Echelmeyer KA (1986) Stress-gradient coupling in glacier flow: I. Longitudinal averaging of the influence of ice thickness and surface slope. J. Glaciol., 32(111), 267-284

Kulkarni AV and 6 others (2007) Glacial retreat in Himalaya using Indian remote sensing satellite data. Current Sci., 92(1), 69-74

Kulkarni AV, Rathore BP, Singh SK and Bahuguna IM (2011) Understanding changes in the Himalayan cryosphere using remote sensing techniques. Int. J. Remote Sens., 32(3), 601-615 (doi: 10.1080/01431161.2010.517802)

Leprince S, Barbot S, Ayoub F and Avouac J-P (2007) Automatic and precise orthorectification, coregistration, and subpixel correlation of satellite images, application to ground deformation measurements. IEEE Trans. Geosci. Remote Sens., 45(6), 15291558 (doi: 10.1109/TGRS.2006.888937)

Linsbauer A, Paul F and Haeberli W (2012) Modeling glacier thickness distribution and bed topography over entire mountain ranges with GlabTop: application of a fast and robust approach. J. Geophys. Res., 117(F3), F03007 (doi: 10.1029/2011JF002313)

Lliboutry LA (1987) Very slow flows of solids: basics of modeling in geodynamics and glaciology. Martinus Nijhoff, Dordrecht

McNabb RW and 11 others (2012) Using surface velocities to calculate ice thickness and bed topography: a case study at Columbia Glacier, Alaska, USA. J. Glaciol., 58(212), 1151-1164 (doi: 10.3189/2012JoG11J249)

Müller F (1970) A pilot study for an inventory of glaciers in the Eastern Himalayas. In Perennial snow and ice masses: a guide for compilation and assemblage of data for a world inventory. (UNESCO Technical Papers I Hydrology No. 1) UNESCO, Paris, 47-59

Radić V, Hock R and Oerlemans J (2008) Analysis of scaling methods in deriving future volume evolutions of valley glaciers. J. Glaciol., 54(187), 601-612 (doi: 10.3189/002214308786570809)

Raina VK (2009) Himalayan glaciers: a state-of-art review of glacial studies, glacial retreat and climate change. (MoEF Discussion Paper) Ministry of Environment and Forests, Government of India/GB Pant Institute of Himalayan Environment and Development, New Delhi/Kosi-Katarmal http://www.indiaenvironmentportal.org.in/reports-documents/himalayan-glaciers-stateart-review-glacial-studies-glacial-retreat-and-climate

Raina VK and Srivastava D (2008) Glacier atlas of India. Geological Survey of India, Bangalore

Swaroop S, Raina VK and Sangeswar CV (2003) Ice flow of Gangotri glacier. In Srivastava D, Gupta KR and Mukerji S eds. Proceedings of the Workshop on Gangotri glacier, 26-28 March 2003, Lucknow, India. (Spec. Publ. 80) Geological Survey of India, Kolkata

Venkatesh TN, Kulkarni AV and Srinivasan J (2012) Relative effect of slope and equilibrium line altitude on the retreat of Himalayan glaciers. Cryosphere, 6(2), 301-311 (doi: 10.5194/tc-6-3012012) 